\title{
MEDICAL EXPERIMENTS IN THE LIGHT OF THE AMENDMENT OF THE ACT ON THE PROFESSION OF A PHYSICIAN AND A DENTIST
}

DOI: $10.36740 /$ WLek202108136

\author{
Małgorzata Gąsior \\ LEGAL DEPARTMENT, NCBR+ SP.Z 0.0., WARSAW, POLAND
}

\begin{abstract}
On the 1st of January 2021 the new legal regulations to the Act of 5 December 1996 on the professions of a physician and a dentist came into force. The aim of this article is to present the new legal regulations of conducting medical experiments and to clarify the regulations already applicable. Under the amended regulations, the legislator, comprehensively regulated the legal conditions and rules to conduct the medical experiments, both research experiments and therapeutic ones, by imposing the new restrictions on a person who conducts medical experiments. The most significant change is that examination of biological material, including genetic material collected from a person for scientific purposes, is also regarded as a medical experiment. The purpose of the article is therefore to familiarize medical community with the new legal regulations concerning the principles of conducting all kind of medical experiments and to point out what interpretation doubts and legal dilemmas may arise while their conducting.
\end{abstract}

KEY WORDS: medical experiment, research experiment, therapeutic experiment, biological material, legal act

Wiad Lek. 2021;74(8):1988-1994

\section{INTRODUCTION}

The act regulating the issue of conducting medical experiments is the Act on the professions of a physician and a dentist of December 5, 1996 (Journal of Laws 2020, item 514), from now on referred to as "the Act" [1]. Pursuant to the Act on the profession of a physician of December 5, 1996 (Journal of Laws 1997 No. 28, item 152), in 1996, for the first time in the Polish legal system, the problem of conducting medical experiments on humans was systematized. The act indicated in Art. $21 \mathrm{sec} .1$ that a medical experiment carried out on humans may be a therapeutic or research experiment [2]. A significant breakthrough in the field of Polish medical legislation in the field of medical experiments was the entry into force of the Act of July 16, 2020, amending the Act on the professions of a physician and a dentist and certain other acts (Journal of Laws of 2020, item 1291) [3]. The amending Act introduced new legal regulations and clarified the already applicable in the chapter on medical experiments, the provisions of which came into force on January 1, 2021. The provisions of the amending Act presented many inaccuracies to the medical community in the field of legal conditions for conducting medical experiments under the amended legal regulations. As indicated by the legislator in the justification to the government draft of the amending Act, the necessity of the changes in question resulted from the fact that the existing regulations did not reflect the actual course of medical experiments while preserving patients' rights [4].

\section{THE AIM}

The study aimed to familiarize the medical community with new legal regulations, clarify the already existing regulations governing the conduct of medical experiments, and show what interpretation doubts and legal dilemmas may arise. In addition, the study indicated in detail what new obligations the entity conducting the medical experiment should bear in mind before carrying out a medical experiment and about which such entity must remember during the medical experiment duration.

\section{REVIEW AND DISCUSSION}

\section{SCOPE OF CHANGES}

In the amended Act, the legislator has introduced many changes that only clarify the provisions in force so far and do not change the legal status. However, the new wording of the Act's provisions introduces some significant normative changes from the point of view of the principles of conducting medical experiments. One of such changes, creating a new legal regulation, is the introduction to the catalog of medical experiments, also the testing of biological material, including genetic material, collected from a person for scientific purposes. This is regulated by Art. $21 \mathrm{sec} .4$ of the Act. In the content of the amended Act, the legislator uses the concept of a participant in a medical experiment. Pursuant to Art. $21 \mathrm{sec} .5$ of the Act, the legislator recognizes the person on whom the medical 
experiment is directly conducted, from now on referred to as a "participant". It is an ordering element in relation to the current legal status. The scope of some of the amended regulations applies to both the regulation of the therapeutic and research experiment. However, the principles of conducting research on biological material, including genetic material, have not been comprehensively legally regulated by the changes introduced in the Act.

\section{TESTING OF BIOLOGICAL MATERIAL}

From the point of view of the development of modern medical sciences, submitting to the legal regime the examination of human biological material collected from a person for scientific purposes in accordance with Art. 21 sec. 4 of the Act is one of the most controversial changes to the amended Act. However, the legislator did not make any attempt to define the biological material itself. Literature defines biological material, among others, as each sample of a human organ, tissue, body fluids, blood, urine, hair, nails, or teeth, as well as substances obtained directly from these samples [5]. At this point, it should be noted that the activity in the field of collecting, processing, storing, and distributing biological material for scientific purposes, regulated by the Act of July 1, 2005, on the collection, storage, and transplantation of cells, tissues, and organs is not a medical experiment referred to in Art. 29a sec. 2 of the Act. Pursuant to the amended Act, tests of biological material may be conducted by a person other than a doctor who has the necessary qualifications. In cases where the research of biological material will contain a medical part, the person in charge of the research is obliged to cooperate with a doctor with a specialization in the field of medicine, which is particularly useful due to the nature or course of the experiment and the doctor has appropriately high professional and research qualifications, pursuant to Art. $23 \mathrm{sec} .3$ of the Act. Only the doctor supervises the medical part of the experiment.

Another problem of interpretation relates to the vagueness of regulations regarding the necessity to take out third-party liability insurance in the case of biological material testing. In particular, if biological material left after medical procedures or taken from a corpse was used to study biological material. From the literal wording of the regulations, it should be concluded that each collection of biological material, including genetic material collected for scientific purposes, constitutes a medical experiment. However, when researching biological material, there is no subject that is a participant in the experiment, and therefore it is not possible to cause damage to a person. This would mean that each time it is necessary to identify the person who may be directly affected by the experiment effects and should be covered by third-party liability insurance. The legislator also failed to regulate the minimum amount of liability insurance for this type of medical experiment. This raises another problem in interpreting the regulations concerning the situation when biological material collected from a person for scientific purposes will be tested. However, we must remember that following Art. 23c sec. 1 of the Act, a medical experiment may be carried out after the entity conducting the medical experiment has concluded a third-party liability insurance contract; therefore, if it is planned to test biological material for scientific purposes, it is necessary to take into account the necessity to conclude a third-party liability insurance contract for the benefit of the person who can be directly affected by the experiment effects.

\section{COMPULSORY LIABILITY INSURANCE}

A significant change in the Act's provisions is an extension and supplementation of the obligation to conclude a third-party liability insurance contract, vide Art. $23 \mathrm{c}$ of the Act. First of all, the amendment to the Act identifies new entities and does not specify their legal definitions. Problems with interpreting the provisions may arise, particularly in terms of indicating who is obliged to conclude a third-party liability insurance contract and indicating the entity conducting the medical experiment, as well as the person who may be directly affected by the effects of the medical experiment. From the literal wording of the Act's provisions, it could be concluded that the entity conducting the medical experiment could be both the research center and the person in charge of the medical experiment. Due to the doubts that arose as to the definition of the entity conducting the medical experiment, the Presidium of the Supreme Medical Council, in its position of December 4,2020 , indicated the need to clarify the regulation of the Minister of Finance, Funds, and Regional Policy of December 23, 2020, on compulsory third-party liability insurance of the entity conducting the medical experiment (Journal of Laws of 2020, item 2412), from now on referred to as: "the regulation" [6]. Doubts as to the interpretation of the objective and subjective scope of the regulation mentioned above forced the Ministry of Health to issue a communication of February 12, 2021, on the application of the regulation. In the announcement, the Ministry of Health explicitly indicated that the obligation to contracting third-party liability insurance applies to entities that carry out medical experiments, which include:

a) within the institutional understanding, organizational units of universities and research institutes, as well as other medical entities that are entities regulated in Art. 7 of the Act of July 20, 2018, Law on Higher Education and Science, operating in the field of medical sciences and health sciences;

b) healthcare entities, e.g., hospitals, in the case of declaring a medical experiment as a research project of a given unit, simultaneously acting as entities on the premises of which the experiment is carried out [7].

Notwithstanding the above, interpretational doubts may also appear concerning "a person who may be directly affected by the experiment's effects". This person must also be covered by third-party liability insurance, pursuant to Art. $23 \mathrm{c} \mathrm{sec} .1$ of the Act, due to the negative effect of a medical experiment that may occur on that person. However, the legislator has not indicated what kind of effect 
could potentially happen and has not stated any closed catalog of entities belonging to the group of "people who may be directly affected by the experiment's effects". We can presume that they are the parents or legal guardians who take care of the participant and are legal representatives. The analysis also requires clarifying the situations indicated in the Act concerning the vague phrase "being directly affected by the effects of the experiment" used by the legislator. To determine the possible effects of a medical experiment that could directly affect a third party, it would be necessary to look at the type of damage that could be caused. During the medical experiment, damage may be caused by the action or omission of the entity conducting the medical experiment, as provided for in Art. 2 of the regulation [8]. The above indicates a broad understanding of the damage resulting from a medical experiment. From a practical point of view, we can assume that any damage that violates the social integrity of the participants and their rights, as well as personal data protection or security, will have a direct effect on a third party, which may be, for example, a legal representative of a participant in a medical experiment. In particular, if the result of this violation is body injury, death, or health disorder, with the provision, however, that such a person will be able to prove a causeand-effect relationship between the act or omission of the entity conducting the medical experiment and the damage caused. Doubts as to the application of the provisions also concern the guaranteed sum of insurance indicated in the regulation, as well as the scope and necessity to cover with compulsory third-party liability insurance for research experiments and tests of biological material collected from humans.

In the current legal status, third-party liability insurance covers persons who are to participate in a medical experiment following paragraph $4 \mathrm{sec}$. 2 point 4 of the Regulation of the Minister of Health and Social Welfare of May 11, 1999, on the detailed rules for the appointment and financing as well as the mode of operation of bioethical committees (Journal of Laws 1999 item 480) [9]. The scope of medical experiments was regulated only by a subsidiary clause extending the third-party liability insurance policy provisions. As it results from the provisions, the obligation to conclude a third-party liability insurance agreement before the commencement of a medical experiment may be waived only in an urgent situation that directly threatens the participant's life in the therapeutic experiment, as provided for in Art. $23 \mathrm{c} \mathrm{sec} .2$ of the Act. It should be remembered that the obligation to ensure civil liability arises at the latest on the day preceding the date of commencement of the medical experiment, as stated in paragraph 3 of the Regulation of the Minister of Finance, Funds, and Regional Policy of December 23, 2020. Unlike the existing legal provisions, the regulation specifies in paragraph 4 the minimum guaranteed amount of civil liability insurance. It should be noted here that some of the hitherto concluded third-party liability insurance policies directly excluded the effects of a medical experiment from insurance coverage. In the justification of the legal committee reviewing the draft of the regulation mentioned above; however, it was emphasized in the regulation that in the case of high-risk medical experiments, the civil liability insurance contract should be concluded for a higher guarantee sum, adequate to the risk that could potentially occur during the experiment [10].

\section{THE PERSON IN CHARGE OF THE MEDICAL EXPERIMENT}

Under the amended act, pursuant to Art. $23 \mathrm{sec}$. 1, a medical experiment is led by a doctor with a specialization in medicine, which is particularly useful due to the nature or course of the experiment, and with appropriately high professional and research qualifications. The previous wording of the Act indicated only that a highly qualified physician could lead the medical experiment. Concerning the research experiment, the subjective scope of the persons managing the research experiment has been extended. Currently, in the part of the research experiment containing the non-medical part, the doctor in charge of the experiment is obliged to cooperate with another person having the qualifications necessary to carry out the non-medical part. This person supervises the course of this part of the research experiment, vide Art. 23 sec. 2.

\section{SUBJECT LIMITATIONS OF THE RESEARCH EXPERIMENT}

The provision of Art. 23a sec. 1 of the Act determines who is not allowed to be enrolled in a research experiment. The range of such persons has also been extended to include another person dependent on a hierarchical basis limiting the freedom of free consent and a person in detention, i.e., a person forcibly placed in a psychiatric hospital, the conditions of which are regulated by the Act of August 19, 1994, on the protection of mental health (Journal of Laws 2020, item 685) [11]. In addition, the Act clarifies and extends the conditions for the admissibility of conducting a research experiment on a participant who is a minor to include the premise of a significant extension of medical knowledge, pursuant to Art. 23a sec. 2 point 2 of the Act. The admissibility of conducting such an experiment on a minor occurs not only when the expected benefits will directly impact the minor's health but also when the expected benefits will be significant for the health of other minors belonging to the same age group. However, the regulations for the participation of a minor in a research experiment are not strict. This particularly applies to the condition of "bringing a significant extension of medical knowledge through a research experiment". It imposes an obligation for the entity conducting the medical experiment to prove the essence of extending medical knowledge. The vagueness of the premises assessed by the bioethics committee may have a decisive influence on its opinion. The applicant participating in the meeting will have to indicate and justify the fulfillment of the conditions determining the possibility of conducting a specific research experiment with the participation of a minor. In the event 
of a difference in assessment as to whether this condition is met, the applicant may appeal. Another significant change is the lowering of the minor's age compared to the provisions of the amended Act, which regulated the scope of admissibility of conducting a medical experiment on a minor who is or under 16 years of age.

\section{PROHIBITION OF OFFERING INCENTIVES AND FINANCIAL GRATIFICATIONS}

The amended Act prohibits offering participants of medical experiments, with the exception of adult participants who can express legally effective consent, and with the exception of healthy participants, any incentives and financial rewards, in accordance with Art. 23b sec. 1 of the Act. The exceptions indicated in the provision may raise interpretation problems due to its wording, which would require clarification. From the analysis of the provision in question, we can conclude that it is not allowed to apply any incentives or financial gratifications to minor participants, partially or fully incapacitated persons, as well as to participants who are persons with full legal capacity, but not able to express their consent with discernment. The prohibition on offering incentives and financial rewards also applies to medical experiments involving participants who are sick. In the new wording of the Act, in Art. 23b sec. 2, the legislator has also introduced an unequivocal prohibition to conduct a medical experiment in a situation where the compulsory position of an experiment participant was used.

\section{EXTENDED SCOPE OF INFORMATION OBLIGATIONS}

The amended act extends the information obligations towards the participants or their legal representative, presented understandably in oral and written form, following Art. $24 \mathrm{sec} .1$ of the Act. The catalog of information to be obligatorily obtained by the participants or their statutory representatives has been clarified and extended. Following Art. 24 sec. 2 of the Act, the gathered information concerns ensuring respect for private life and confidentiality of personal data, access to relevant information, information on the possibility of further use of the results of the experiment, data, and biological material collected during it, including its use for commercial purposes. At the same time, these people should obtain information about the source of funding for the medical experiment as well as the rules and possibilities of accessing the experimental treatment. The participant is also assured that the refusal to grant consent or withdrawal of consent at any time, without giving a reason, will not claim any negative legal consequences, following art. $24 \mathrm{sec} .3$ of the Act.

\section{THE CONSENT TO PARTICIPATE}

\section{IN A MEDICAL EXPERIMENT}

In the light of the amended Act, the age of a minor has been lowered, in respect to which the minor's consent is required as a participant in a medical experiment or next to the consent expressed by the statutory representative, following the provisions of Art. 25 of the Act. In the previous legal status, the act provided for the possibility of a minor to participate in a medical experiment, directly indicating the age limit of 16 years. Controversial from the point of view of the amended Act is the reduction of the age limit of a minor to 13 years, when serious doubts may arise from the level of awareness and discernment of a minor as to expressing consent to participate in a medical experiment. Concerning participation in a medical experiment of a minor under 13 years of age, the legislator indicates, by analogy with the previous wording of the provisions, the need to obtain the consent of the statutory representative. If a minor has reached the age of 13 , it is necessary to obtain the cumulative consent of both that person and his/her legal representative. In the event of a disagreement between them, the dispute will be resolved by the guardianship court. The provisions regulate several situations for which granting the participant's consent is separately regulated, as it was in the current wording of the provisions, i.e., also concerning a fully incapacitated person and a partially incapacitated person. Pursuant to the amended Act, the legal guardian gives consent to the participation of a completely incapacitated person in a therapeutic experiment unless the incapacitated person has sufficient discernment. In such a situation, participation in the experiment also requires the consent of that person. However, in a situation where a partially incapacitated person does not remain under parental authority, consent is required to participate in the therapeutic experiment of the probation officer and that person, and the guardianship court also resolves the dispute between them. Concerning a research experiment, the lack of consent of the statutory representative or participant makes the conduct of such an experiment prohibited. It should be emphasized that in some cases, both the legal representative of the participant and the entity intending to conduct a medical experiment may apply for court authorization to participate in a medical experiment.

\section{THERAPEUTIC EXPERIMENT WITHOUT LEGALLY REQUIRED CONSENT}

In addition to the general rules for conducting a therapeutic experiment regulated in Chapter 4 of the Act, the legislator details the specific scope of the permissibility of conducting a therapeutic experiment without the necessary consent. In the current wording of the provisions, the legislator has introduced a closed catalog of conditions for the possibility of conducting a therapeutic experiment without the required consent, pursuant to Art. 25a of the Act. This catalog significantly limits the possibility of conducting a therapeutic experiment. In the current legal status, the main condition for the possibility of conducting a therapeutic experiment without the required consent is the urgent situation, indicating a direct threat to life. Currently, conducting a treatment experiment without the 
necessary consent is possible after all additional conditions are met. These premises indicate the inability to conduct an experiment of comparable effectiveness on people who are not in an urgent situation. Additionally, the participant has not previously objected to participation in such an experiment and provided that he/she receives all relevant information as soon as possible.

\section{NO RESTRICTION OF ACCESS TO MEDICAL PROCEDURES}

Pursuant to the amended regulations, it was explicitly regulated that participation in a medical experiment may not limit the participant's access to the necessary medical, diagnostic, or therapeutic procedures in any way. At the same time, participation in the experiment can neither delay, let alone deprive of access to these procedures at all, which is provided for in Art. 26 sec. 1 of the Act. Moreover, it is indicated that a participant assigned to a given control group is obliged to use only proven prophylactic, diagnostic, or therapeutic methods following Art. $26 \mathrm{sec}$. 2 of the Act. Although introducing the so far not directly regulated legal norm prohibiting the restriction of access to medical procedures, the above amendment to the provisions de facto confirms the legal status already existing before the entry into force of the amended provisions. This was due to the principle of equal access to healthcare services financed from public funds, pursuant to Art. 68 sec. 2 of the Constitution of the Republic of Poland of April 2, 1997 (Journal of Laws of 1997, item 483) [12]. However, the normative nature of the introduced change may be due to the fact that such a norm in the current wording of the provisions has not resulted directly from the amended Act. However, considering the imprecise nature of the existing provisions on the conduct of medical experiments, we should note that the amendment was intended to explain the inaccurate intention of the legislator following the wording of the existing provisions.

\section{PLACEBO ADMINISTRATION}

In the new wording given by the amending Act, provisions of the Act also regulated the possibility of using a placebo in Art. $26 \mathrm{sec}$. 3. Since the amended provisions have been in force, the use of a placebo is allowed only in cases where no methods of proven effectiveness exist or if the withdrawal or suspension of these methods does not constitute an unacceptable risk or burden for the participant. The same as in the case of the ban on limiting access to medical procedures, and in the cases of using a placebo, its principles have been actually in force. The principles of conducting scientific research with the participation of humans are regulated in paragraph 33 of the general principles of the Helsinki Declaration of the World Association of Physicians [13]. However, due to the lack of the indications in question in the Act, it was necessary to introduce a legal norm resulting directly from the regulations, which clarifies the principles applied in practice and reflected in other normative acts.

\section{USE OF INFORMATION}

The Act has emphasized that the use for scientific purposes of information obtained not only in connection with the medical experiment itself but also the screening tests is possible without the participant's consent, which is regulated by Art. 28 of the Act. However, the condition for such use of information is obligatory anonymization of the data, which does not allow the identification of the participant. The lack of regulations in Polish law on the possibility of using information obtained in connection with the screening tests forced the necessity to regulate the possibility of using the information in question to prevent the identification of the screening test participant. It should respect the right to privacy and the protection of personal data, following Regulation (EU) 2016/679 of the European Parliament and of the Council of April 27, 2016, on the protection of individuals concerning the processing of personal data and the free movement of such data and repealing Directive 95/46/EC (General Data Protection Regulation) (Journal of Laws UE of 2016 No. 119/1) [14]. At the same time, it should be emphasized that the International UNESCO Declaration on Genetic Data of October 16, 2003 already indicated in Art. 5 (i) on the possibility of processing genetic data for the purpose of screening [15].

\section{BIOETHICS COMMITTEE}

Due to significant changes in the conduct of medical experiments introduced by the legislator in the Act, it was necessary to regulate the activities of bioethics committees in detail. At this point, attention should be paid in particular to the new wording of the provision, to the extent that the applicants may also participate in the meeting of the bioethical commission in the part of the meeting concerning the presentation of their application, the expert issuing an opinion on a given medical experiment, and the secretary of the commission, vide Art. $29 \mathrm{sec} .13$ of the Act. Until now, the Act has not directly regulated who can participate in the meetings of the bioethics commission. The scope of participation in the meeting of the bioethical commission of the entity intending to conduct a medical experiment was indicated only in a narrow scope by paragraph $6 \mathrm{sec}$. 3 of the Regulation of the Minister of Health and Social Welfare of May 11, 1999, on the detailed rules for the appointment and financing and the mode of operation of bioethical committees. However, the regulations of the bioethical commission's work could provide the possibility of inviting to participate in part or all of the bioethical commission meeting also persons representing the entity applying for an opinion on a medical experiment, an expert issuing an opinion on a given medical experiment, and other persons representing social or interest groups. Considering the above, it should be concluded that the essence of the introduced change in the legal regulation of the extended personal scope of persons who may participate in the meetings of the bioethics commission is that the participation of these persons was previously considered permissible. Still, it depended on the will of the bioethics commission itself. In the current legal 
situation, the participation of these people has become a statutory right, resulting directly from the provisions of the amended act. Thus, the amendment to the Act has legally regulated the subjective scope of the persons listed in the Act who may participate in the meetings of the bioethics commission and those who have already participated in the meetings at the will of the bioethics commission's decision. In addition, both the applicant and the head of the entity where the medical experiment is to be conducted and the bioethical commission competent for the center that is to participate in a multicenter medical experiment may appeal against the resolution of the bioethics commission, pursuant to Art. $29 \mathrm{sec} .15$ of the Act. Currently, the rules for the appointment and financing as well as the operating modes of the bioethics commission are regulated by the regulation of the Minister of Health and Social Welfare of May 11, 1999, on the detailed rules for the appointment and financing and the procedure of bioethical commission operation, which will, however, be repealed and will cease to apply on July 1, 2022, after the entry into force of the implementing provisions.

\section{BREACH OF LEGAL PROVISIONS}

Considering the extended scope of legal regulations regarding the conduct of medical experiments and the change in the nature of the violations that may occur, the legislator, pursuant to the amended provisions, provided for new penal sanctions. In line with the above, the catalog of criminal sanctions for violating the principles of conducting medical experiments provides for a fine, restriction of liberty, or imprisonment, respectively, pursuant to Art. 58 of the Act.

\section{CONCLUSIONS}

Amendment to the Act has become an essential step towards a comprehensive legal regulation of the possibility of conducting medical experiments because the existing regulations in the then wording were incomplete, and the lack of systemic regulation of this issue constituted a serious legal loophole. The legislator has attempted to regulate in detail the issues related to medical experiments, including their definition, conditions for carrying them out, or the conditions for conducting them without the necessary consent. The extended obligation to conclude third-party liability insurance contracts, particularly concerning the testing of biological material, has become widely commented on in the legal community. When analyzing the scope of the regulations of the amended Act, it should be concluded that a large part of the legal regulations in the field of conducting medical experiments is defective or incomplete. At this point, the Act poses more legal dilemmas for entities conducting the medical experiment than answers to the bothering issues of the possibility of using specific research methods. It should be borne in mind that failure to comply with the amended legal provisions may lead to criminal liability due to the detailed sanctioning of the rules for conducting medical experiments.

\section{REFERENCES}

1. Ustawa z dnia 5 grudnia 1996 r. o zawodach lekarza i lekarza dentysty. Dz.U. 2020 poz. 514.

2. Ustawa z dnia 5 grudnia 1996 r. o zawodzie lekarza. Dz.U. 1997 nr 28 poz. 152.

3. Ustawa z dnia 16 lipca 2020 r. 0 zmianie ustawy o zawodach lekarza i lekarza dentysty oraz niektórych innych ustaw Dz.U. 2020 poz. 1291.

4. Uzasadnienie, druk nr 172 Rządowy projekt ustawy o zmianie ustawy 0 zawodach lekarza i lekarza dentysty oraz niektórych innych ustaw. 16.01.2020 r.

5. Różyńska J., Waligóra M. Badania naukowe na ludzkim materiale biologicznym. In: Krajewska A. Badania naukowe z udziałem ludzi w biomedycynie. Standardy międzynarodowe. Warszawa: Wolters Kluwer Polska; 2012, p. 183.

6. Stanowisko nr 139/20/P-VIII Prezydium Naczelnej Rady Lekarskiej z dnia 4 grudnia 2020 r. w sprawie projektu rozporządzenia Ministra Finansów, Funduszy i Polityki Regionalnej w sprawie obowiązkowego ubezpieczenia odpowiedzialności cywilnej podmiotu przeprowadzającego eksperyment medyczny.

7. Pismo z dnia 12 lutego 2021 r. Ministerstwo Zdrowia, RKN.07.21.2021. E0, Komunikat Ministra Zdrowia w sprawie stosowania rozporządzenia Ministra Finansów, Funduszy i Polityki Regionalnej z dnia 23 grudnia 2020 r. w sprawie obowiązkowego ubezpieczenia odpowiedzialności cywilnej podmiotu przeprowadzającego eksperyment medyczny.

8. Rozporządzenie Ministra Finansów, Funduszy i Polityki Regionalnej z dnia 23 grudnia 2020 r. w sprawie obowiązkowego ubezpieczenia odpowiedzialności cywilnej podmiotu przeprowadzającego eksperyment medyczny. Dz.U. 2020 poz. 2412.

9. Rozporządzenie Ministra Zdrowia i Opieki Społecznej z dnia 11 maja 1999 r. w sprawie szczegółowych zasad powoływania i finansowania oraz trybu działania komisji bioetycznych. Dz.U.1999 poz. 480.

10. Uzasadnienie komisji prawniczej $z$ dnia 08.03 .2021 r. do projektu rozporządzenia Ministra Finansów, Funduszy i Polityki Regionalnej w sprawie obowiązkowego ubezpieczenia odpowiedzialności cywilnej podmiotu przeprowadzającego eksperyment medyczny. [https:// legislacja.rcl.gov.pl/projekt/12340261/katalog/12737662\#12737662 Access: 06.04.2021].

11. Ustawa z dnia 19 sierpnia 1994 r. o ochronie zdrowia psychicznego (Dz.U.2020 poz.685).

12. Konstytucja Rzeczypospolitej Polskiej z dnia 2 kwietnia 1997 r. Dz.U. 1997 poz. 483.

13. Deklaracja Helsińska Światowego Stowarzyszenia Lekarzy (WMA), przyjęta przez 18 Zgromadzenie Ogólne Światowego Stowarzyszenia Lekarzy (WMA), Helsinki, Finlandia, czerwiec 1964r., wraz z późn. zm.

14. Rozporządzeniem Parlamentu Europejskiego i Rady (UE) 2016/679 z dnia 27 kwietnia 2016 r. w sprawie ochrony osób fizycznych w związku z przetwarzaniem danych osobowych i w sprawie swobodnego przepływu takich danych oraz uchylenia dyrektywy 95/46/WE (ogólne rozporządzenie o ochronie danych). Dz. Urz. UE L z 2016 r. nr 119/1.

15. Międzynarodowa Deklaracja UNESCO w sprawie danych genetycznych z dnia $16.10 .2003 \mathrm{r}$.

\section{ORCID and contributionship}

Matgorzata Gąior: 0000-0001-9899-4602 A,B,D-F

\section{Conflict of interest:}

The Author declare no conflict of interest. 


\section{CORRESPONDING AUTHOR}

Małgorzata Gąsior

Legal Department, NCBR+ sp. z 0.0., Warsaw, Poland

e-mail:malgorzatagasior77@gmail.com

Received: 13.05 .2021

Accepted: 30.07 .2021

A - Work concept and design, B - Data collection and analysis, C - Responsibility for statistical analysis,

D-Writing the article, $\mathbf{E}-$ Critical review, $\mathbf{F}$ - Final approval of the article 